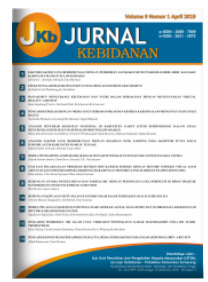

Volume 9 Nomor 2 (2019) 142-147

JURNAL KEBIDANAN

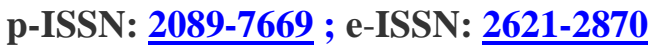

http://dx.doi.org/10.31983/jkb.v9i2.4819

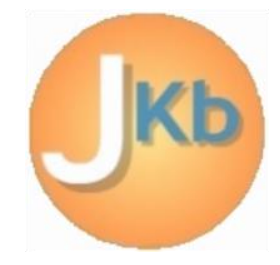

\title{
The Effect of Experience Extension on the Activity of Calculating Fetal Movement Third Trimester of Primiparous
}

\author{
I Gusti Ayu Putu Sri Wahyuni ${ }^{1}$ Fitra Arsy Nur Cory'ah ${ }^{2}$ \\ ${ }^{1,2}$ Jurusan Kebidanan, Poltekkes Kemenkes Mataram. Indonesia \\ Corresponding author: I Gusti Ayu Putu Sri Wahyuni \\ Email: gmanik66@yahoo.com
}

Received: July 1st 2019; Revised: October 1st 2019; Accepted: October 16th 2019

\begin{abstract}
Based on research by the World Health Organization (WHO), around the world there are $10,000,000$ infant deaths per year in Indonesia, among ASEAN countries, is the country with the highest perinatal mortality rate, meaning that the ability to provide health services still requires improvements that are comprehensive and of higher quality. Integrated ANC services are also related to effective counseling activities in an effort to improve maternal knowledge about pregnancy care, especially the activity of calculating gesture). The purpose of this study is to determine the effect of experimental counseling fetal motion in third-trimester primigravida. The design in this study was pregnant post nonequivalent control group test. The study was conducted in Meninting Community Health Center, West Lombok Regency. The population of this study was the third trimester of pregnant women, namely 80 people. The sample of this study was 34 people. Test statistics using the Mann Whitney test and Fisher's Exact Test with confidence levels specified $\alpha=0.05$ and $95 \%$ confidence intervals. The results of the study with the Mann Whitney test $\mathrm{P}=0,000$ means that there is a significant difference between knowledge about calculating fetal motion in the case group compared to the control group and the Fisher's Exact Test $P=0,000$ shows there is an influence of experimental counseling on the activity of calculating fetal movement. The recommendations of this study are to examine the effectiveness of calculating fetal motion for fetal distress
\end{abstract}

Keywords: experimental counseling; fetal movement

\section{Pendahuluan}

Pembangunan kesehatan secara global memiliki tujuan yang ketiga yaitu menjamin kehidupan yang sehat dan mendorong kesejahteraan bagi semua orang disegala umur pada tahun 2030, dengan target mengurangi AKI (Angka Kematian Ibu) hingga 70 PER $100.000 \mathrm{KH}$ (Kelahiran Hidup), dan mengakhiri kematian bayi dan balita yang dapat dicegah dengan menurunkan kematian neonatal hingga 12 per $1000 \mathrm{KH}$ dan indikator lain yaitu menilai angka kematian perinatal atau PMR (Perinatal Mortality Rate) yang merupakan penyumbang terbesar tingginya angka kematian bayi di Indonesia. Berdasarkan data WHO tahun 2013, angka kemtian perinatal yaitu 47/1000 Kelahiran Hidup, di Asia Tenggara yaitu $33 / 1000 \mathrm{KH}$, sedangkan di Indonesia 26/1000 KH, Nusa Tenggara Berat merupakan salah satu 5 besar Provinsi di Indonesia yang memiliki PMR 38/1000 $\mathrm{KH}$. Demikian juga halnya dengan angka kejadian IUFD, Berdasarkan penelitian World Health Organization (WHO) diseluruh dunia, terdapat kematian bayi sebesar 10.000.000 jiwa per tahun, Indonesia, diantara Negara ASEAN merupakan Negara dengan angka kematian perinatal tertinggi,yang berarti kemampuan untuk memberikan pelayanan kesehatan masih 
memerlukan perbaikan yang bersifat menyeluruh dan lebih bermutu. [1]

Indikator diatas yaitu PMR dapat digunakan untuk menilai kwalitas Antenatal Care (ANC) dan Perinatal Care. Standar pemantauan kehamilan diperoleh melalui ANC, dengan tujuan deteksi dini dan mencegah komplikasi pada ibu dan janin [2] khususnya komplikasi yang terjadi pada janin dengan menghitung gerak janin pada kehamilan trimester 3. Berdasarkan penelitian Eli aastadmenyatakan bahwa menghitung gerakan janin dapat menginterpretasikan kesejahteraan janin, dan identifikasi kejadian gangguan pertumbuhan janin serta kondisi perinatalnya. Pelayanan ANC (10 T) terpadu juga terkait dengan kegiatan penyuluhan yang efektif dalam upaya meningkatkan pengetahun ibu tentang perawatan kehamilan khususnya Keaktifan menghitung gerak janin [3]

Salah satu Puskesmas di kabupaten Lombok Barat yang telah melaksanakan ANC terpadu yaitu UPT Puskesmas Meninting dengan jumlah ibu hamil pada tahun 2017 yaitu 1480 orang dan 2018 yaitu 1093 orang dan bumil TM 3 yaitu 80 orang di wilayah desa Meninting dan memiliki kasus IUFD sejumlah dari 1287 kelahiran.

\section{Metode Penelitian}

Penyuluhan merupakan teknik atau metode yang digunakan menyampaikan suatu informasi, edukasi dan komunikasi efektif, dengan tujuan memberikan perubahan yang positif kepada masyarakat. Keberhasilan dari penyuluhan terbentuk dari hasil perubahan perilaku. Terjadinya perubahan perilaku dimotivasi oleh faktor psikologis (internal) dan lingkungan (eksternal), yang dipengaruhi oleh komponen intelektual (kognitif) dan emosional (afektif) .[4]

Desain dalam penelitian ini adalah Quai experiment dengan pendekatan pre and post test non desaig witht control group dengan intervensi penyuluhan metode eksperiensial, yaitu kelompok eksperimen maupun kelompok kontrol tidak dipilih secara random, kemudian sebelumnya diberi pre test untuk mengetahui keadaan awal antara kelompok eksperimen dan kelompok kontrol" [5] Selanjutnya setelah diketahui hasil dari pretest dua kelompok tersebut, maka pada kelas eksperimen diberikan perlakuan $(\mathrm{X})$, sedangkan pada kelas kontrol tidak diberikan perlakuan (X).Setelah diberikan perlakuan atau treatment pada salah satu kelompok sampel (kelompok eksperimen) dilanjutkan dengan pemberian posttest pada kedua kelas atau kedua kelompok sampel yang digunakan. Penyuluhan dilakukan secara klasikal, masing-,masing sesi selama 30 menit. Pengaruh perlakuan disimbolkan dengan (O2-O1)-(O4-O3) dan selanjutnya untuk melihat pengaruh perlakuan berdasarkan signifikasinya adalah dengan menggunakan uji statistik parametrik Fisher Excat tes. k.Jika terdapat perbedaan yang signifikan antara kelompok eksperimen dengan kelompok kontrol, maka perlakuan yang diberikan berpengaruh secara signifikan.

Populasi dan sampel, Populasi penelitian ini adalah seluruh ibu hamil trimester III yang usia kehamilan 28 - 38 minggu di UPT BLUD Puskesmas Meninting sebanyak 80 orang dan sampel penelitian adalah Ibu hamil primigravida trimester III berjumlah 30 orang, yaitu 15 orang sebagai kelompok perlakukan (kasus) dan 15 orang sebagai kelompok kontrol. Sampel dalam penelitian ini menggunakan jumlah sampel untuk penelitian eksperimen yang menggunakan kelompok intervensi dan kelompok kontrol, dengan jumlah anggota sampel masing-masing kelompok 10 sampai dengan 20. Untuk mengantisipasi $10 \%$ drop out, besar subjek perkelompok dilakukan estimasi penambahan, adapun rumus yang digunakan untuk koreksi jumlah sampel adalah;

Berdasarkan perhitungan diatas, jumlah sampel masing-masing kelompok adalah 17 responden. Pengambilan sampel secara purposive sampling.

Alat dan cara penelitian, penelitian menggunakan kuisioner, Gelang FMC dan FMC Chard. Variabel terikat adalah kepatuhan menghitung dan variabel bebas adalah penyuluhan eksperiensial. Pengolahan data Penelitian ini menggunakan uji Chi Square, karena skala data berbentuk nominal dan nominal dengan tingkat kepercayaan ditentukan $\alpha=0,05$ dan confidence interval $95 \%$. Sebelum melakukan penelitian, terlebih dahulu peneliti telah mendapatkan persetujuan etik dari Komisi Etik Penelitian Kesehatan Universitas Mataram dengan No 182/UN18.8/ETIK/2018.

\section{Hasil dan Pembahasan}

Berdasarkan hasil penelitian karakteristik responden disajikan dalam kelompok kasus yaitu primigravida mendapat penyuluhan ANC rutin berjumlah 17 orang dan kelompok control adalah primigravida mendapat penyuluhan eksperiensial berjumlah 17 orang sehingga jumlah total sampel 
adalah 34 orang, karakteristik responden meliputi umur, pendidikan dan usia kehamilan dapat dilihat pada tabel 1 berikut ini

Tabel 1

Karakteristik Responden

\begin{tabular}{lccc}
\hline Karakteristik & Kasus & Kontrol & $\mathrm{P}$ \\
\cline { 2 - 3 } & $\mathrm{n}=17$ & $\mathrm{n}=17$ & \\
\hline Umur & & & $0,649^{*}$ \\
Mean \pm SD & $27,5 \pm 4$, & $32,6 \pm 2,4$ & \\
Min-Mak & 9 & & \\
Pendidikan & $18-40$ & $28-37$ & \\
SD & 3 & $5(29,4 \%)$ & \\
& $(17,6 \%)$ & & \\
SMP & $7(41,2$ & $7(41,2 \%)$ & \\
& $\%)$ & & \\
SMA & $7(41,2$ & $5(29,4 \%)$ & \\
Umur & $\%)$ & & $0,764 *$ \\
Kehamilan & & & \\
Mean \pm SD & $32,6 \pm 2$, & $32,6 \pm 2,4$ & \\
Minimal- & 4 & & \\
Maksimal & $28-37$ & $28-37$ & \\
\hline Ket: & & & \\
\hline
\end{tabular}

Ket:*)Shapiro-Wilk**)Chi-Square

Berdasarkan hasil penelitian pada tabel 1 diatas dapat dilihat karakteristik responden pada kedua kelompok yaitu kelompok perlakukan (kasus) dan kelompok kontrol seluruhnya adalah bersifat homogen atau memiliki data yang berdistribusi normal antara lain: pada umur responden dengan menggunakan uji Shapiro-Wilk menunjukkan nilai $\mathrm{P}=0,649$ artinya lebih besar dari nilai $\mathrm{P}<0,05$, sehingga data umur responden dapat disebut homogen. Selanjutnya untuk tingkat pendidikan antara kelompok intervensi dan control dianalisis dengan Chi Square memiliki hubungan signifikasi dengan nilai $\mathrm{P}=0,04$ lebih kecil dari $\mathrm{P}=$ 0,05 , sedangkan pada usia kehamilan tidak ada perbedaan rerata antara kelompok intervensi dan kelompok control dengan nilai rata-rata adalah 32,6 dan dilakukan uji homogenitas dengan uji Shapiro-Wilk menunjukkan nilai $\mathrm{P}=0,764$ artinya lebih besar dari nilai $\mathrm{P}<0,05$, sehingga data umur kehamilan responden disebut homogen.

Faktor umur, pendidikan dan pekerjaan, usia kehamilan dan jumlah kehamilan (gravida) tingkat pendidikan sering dikaitkan dengan keaktifan seseorang dalam melakukan tindakan, namun pada penelitian ini tidak dianalisa pengaruh umur, usia kehamilan, tingkat pendidikan terhadap kepatuhan menghitung gerak janin, karena sudah dibatasi dalam kriteria inklusi. Tetapi dalam penelitian ini umur, usia kehamilan dan tingkat pendidikan merupakan variabel pengganggu. Berdasarkan hasil uji statistik, perbandingan karakteristik responden antar kelompok didapatkan semua nilai $p>0,05$, artinya bahwa tidak terdapat perbedaan yang signifikan rerata umur, usia kehamilan, tingkat pendidikan antara kelompok intervensi (kasus) dengan kelompok kontrol, sehingga umur, usia kehamilan, tingkat pendidikan responden sebagai variabel pengganggu dalam penelitian ini sudah dapat dikendalikan. Berikut pembahasan dari masing - masing karakteristik responden:

\section{a. Umur Responden}

Hasil penelitian menunjukkan bahwa keseluruhan responden pada penelitian ini berumur antara 18 -40 tahun dengan rerata umur 30 tahun (27,5 sampai dengan 32,6 tahun). Sesuai dengan tahap perkembangannya, umur para responden tergolong dalam dewasa muda yang memungkinkan responden sudah dapat berpikir matang dan memiliki kemampuan dalam beradaptasi dengan lingkungan sekitarnya termasuk selama menghadapi proses perubahan yang terjadi selama hamil atau menjelang persalinan. Hal ini sesuai dengan teori yang mengatakan bahwa dengan semakin bertambahnya umur kematangan psikologi individu semakin baik, artinya semakin matang psikologi seseorang, semakin baik pula adaptasi terhadap perubahan perilaku.[6]

Secara biologis umur responden tergolong dalam usia reproduksi yaitu usia 20 - 30 tahun. Pada usia tersebut perkembangan alat reproduksi pada seorang wanita sudah sempurna, sehingga ibu yang hamil akan cenderung mengalami proses kehamilan yang lebih sehat. Hal ini sesuai dengan teori yang mengatakan bahwa usia seseorang dapat mempengaruhi keadaan kehamilannya, dimana bila wanita tersebut hamil pada masa reproduksi, kecil kemungkinan untuk mengalami komplikasi dibanding wanita yang hamil dibawah atau diatas usia reproduksi. [7]

\section{b. Usia Kehamilan Responden}

Hasil penelitian menunjukkan bahwa rerata usia kehamilan responden 32,6 minggu atau dengan kata lain rata - rata berusia $28-37$ minggu. Umumnya pada masa kehamilan ini disebut sebagai periode penantian dengan penuh kewaspadaan dan merupakan waktu persiapan 
yang aktif menantikan kelahiran bayinya.Pada fase kehamilan trimester ketiga perubahan-perubahan psikologis pada ibu hamil biasanya semakin kompleks dan meningkat dari trimester sebelumnya.Salah satunya adalah aktivitas janin dimana pada bulan-bulan terakhir menjelang persalinan perubahan gerakan janin menjadi semakin aktif.[8,9]

\section{c. Pendidikan Responden}

Secara umum hasil penelitian ini menunjukkan tingkat pendidikan formal yang dimiliki oleh responden adalah pendidikan dasar dan menengah.Tingkat pendidikan formal merupakan dasar pengetahuan intelektual yang dimiliki seseorang. Dengan pendidikan formal yang dimiliki berarti responden cenderung lebih mudah dalam menerima informasi yang berkaitan dengan seputar kehamilan atau persalinan sehingga akan lebih memudahkan responden dalam beradaptasi terhadap perubahan perilaku. $[10,11,12]$

\section{Analisis Pengetahuan Responden}

Pada pelaksanaan penelitian sebelum melakukan intervensi atau perlakuan di lakukan penilaian awal untuk skor pengetahuan pada kedua kelompok responden dengan menggunakan kuesioner pengetahuan tentang menghitung gerak janin, setelah pre test dilanjutkan dengan intervensi pada kelompok kasus dilakukan penyuluhan eksperiensial menghitung gerak janin dan pada kelompok kontrol tidak diberikan penyuluhan eksperiensial hanya di berikan penyuluhan rutin saat ANC, untuk lebih jelasnya hasil analisis pre dan post test dapat dilihat pada tabel 2 berikut ini.

Tabel 2

Analisis Pre dan Post Skor Pengetahuan Pada Kelompok Perlakuan (kasus) dan Kelompok Kontrol.

\begin{tabular}{lccc}
\hline \multicolumn{1}{c}{ Skor } & Kasus & Kontrol & $\mathrm{P}$ \\
\cline { 2 - 3 } Pengetahuan & $\mathrm{n}=17$ & $\mathrm{n}=17$ & \\
\hline $\begin{array}{l}\text { Pengetahuan } \\
\text { Pre: }\end{array}$ & & & $0,102^{*}$ \\
$\quad$ Rerata & $51,3(7,0)$ & $51,3(6,6)$ & \\
(SD) & & & \\
$\quad$ Median & 50 & 52 & \\
$\quad$ Rentang & 25 & 30 & \\
$\quad$ Min-Max & $42-67$ & $40-60$ & \\
Pengetahuan & & & $0,000^{*}$ \\
Post: & & & \\
$\quad$ Mean Rank & 25,6 & 9,4 &
\end{tabular}

$\begin{array}{lrr}\begin{array}{l}\text { Sum Of } \\ \text { Ranks }\end{array} & 435 & 160 \\ \text { Ket:*)Shapiro-Wilk, **)Mann Whitney }\end{array}$

Berdasarkan table 2 dapat dilihat rerata skor pengetahuan pada saat pre test kedua kelompok responden yaitu kasus dan kontrol adalah sama atau homogen dan telah dibuktikan dengan uji normalitas pada sampel kecil $(<50$ responden) dengan menggunakan Uji Shapiro-Wilk dan memperoleh nilai signifikansi yaitu 0,102 lebih besar dari P-Value 0,05 artinya kedua kelompok responden tersebut adalah berada pada distribusi normal (homogen).

Table 2 juga menunjukkan skor pengetahun post test antara kelompok kasus dan control adalah signifikan dengan nilai P-Value adalah 0,000 lebih kecil dari $\mathrm{P}=0,05$ dengan menggunakan uji MannWhitney hal tersubut berati ada pengaruh penyuluhan eksperiensial pada peningkatan pengetahuan tentang menghitung gerak janin pada kelompok kasus dibandingkan dengan kelompok control yang tidak mendapatkan penyuluhan eksperiensial.

Sebelum perlakuan kedua kelompok memiliki rerata pengetahuan yang sama atau tidak berbeda yaitu 51,3 (nilai $p$ value 0,102 ). Dengan kondisi pengetahuan responden yang sama pada kedua kelompok, sampel dalam penelitian ini sudah homogen, dalam sebuah penelitian eksperimen kondisi responden sudah dapat dikendalikan sehingga ini tidak akan mempengaruhi hasil intervensi yang akan diberikan selama penelitian.

Setelah diberikan perlakuan skor pengetahuan pada kedua kelompok masing masing mengalami peningkatan dan terdapat perbedaan yang bermakna pada rerata skor pengetahuan responden antara kelompok intervensi dengan kelompok kontrol. Hasil penelitian ini menunjukkan bahwa penyuluhan eksperiensial pada kelompok intervensi dan penyuluhan ANC rutin pada kelompok kontrol yang diberikan pada kelas ibu terbukti efektif meningkatkan pengetahuan ibu tentang menghitung gerak janin, karena hasil uji membuktikan adanya perbedaan yang bermakna rerata skor pengetahuan sebelum dan setelah perlakuan pada kedua kelompok.

Meningkatnya pengetahuan pada kelompok intervensi disebabkan karena penyuluhan eksperiensial bertujuan untuk memberikan pengalaman praktek langsung tentang menghitung gerak janin dan diberikan alat berupa gelang $F M C$ yang dapat digunakan sebagai alat untuk 
mempraktekkan menghitung gerak janin secara praktis setiap saat.dimana hasil penelitian menunjukkan bahwa ada korelasi yang signifikan antara pengetahuan sebelum dan sesudah intervensi pada kelompok kasus dan control.

2. Pengaruh Penyuluhan Eksperiensial Terhadap Keaktifan Menghitung Gerak Janin

Pengaruh penyuluhan eksperiensial terhadap keaktifan menghitung gerak janin pada responden di peroleh dengan menggunakan analisis ChiSquare untuk lebih jelas dapat dilihat pada tabel 3 dihalaman berikut ini.

\section{Tabel 3}

Pengaruh Penyuluhan Eksperiensial Terhadap Keaktifan Menghitung Gerak Janin.

\begin{tabular}{lccc}
\hline \multicolumn{1}{c}{ Keaktifan } & Kasus & Kontrol & $\mathrm{P}$ \\
\cline { 2 - 3 } $\begin{array}{c}\text { Menghitung Gerak } \\
\text { Janin }\end{array}$ & $\mathrm{n}=17$ & $\mathrm{n}=17$ & \\
\hline Aktif & 17 & 3 & \\
Tidak Aktif & 0 & 14 & 0,000 \\
\hline
\end{tabular}

Berdasarkan tabel 3 diatas dapat dilihat pada kelompok kasus yang diberikan penyuluhan eksperiensial seluruhya 17 responden aktif menghitung gerak janin sedangkan pada kelompok control yang tidak mendapatkan penyuluhan eksperiensial hanya 3 responden yang aktif menghitung gerak janin dan 14 orang tidak aktif, setelah dianalisis dengan menggunakan uji $C h i$ Square dan diperoleh nilai signifikansi $\mathrm{P}=0,000<$ P-Value 0,05 ini berarti ada pengaruh yang signifikan penyuluhan eksperiensial terhadap keaktifan menghitung gerak janin.

Pada kelompok kasus yang diberikan penyuluhan eksperiensial seluruhya 17 responden aktif menghitung gerak janin sedangkan pada kelompok control yang tidak mendapatkan penyuluhan eksperiensial hanya 3 responden yang aktif menghitung gerak janin dan 14 orang tidak aktif, setelah dianalisis dengan menggunakan uji Fisher's Exact Test dan diperoleh nilai signifikansi $\mathrm{P}=0,000<\mathrm{P}$ - Value 0,05 ini berarti ada pengaruh yang signifikan penyuluhan eksperiensial terhadap keaktifan menghitung gerak janin. Penyuluhan eksperiensial memberikan pengalaman langsung kepada responden mempraktekkan menghitung gerak janin dengan menggunakan alat gelang FMC dan kemudian mencatat hasil penghitungan pada FMC Chard, hal ini akan meningkatakan keaktifan menghitung gerak janin pada ibu hamil karena tersedianya sarana dan prasarana yang praktis setiap saat, hal ini didukung oleh penelitian Ely Sastad bahwa ada pengaruh signifikan penghitungan gerak janin menggunakan metode dengan nilai $\mathrm{P}=0,001 .[13]$

\section{Simpulan}

Setelah dilakukan penelitian dapat ditarik kesimpulan yaitu:Karakteristik responden meliputi umur, pendidikan dan usia kehamilan adalah homogen antara kelompok kasus dan kontrol dengan nilai masing-masing yaitu $\mathrm{P}=0,694,0,04$ dan 0,764Mann Whetney $\mathrm{P}=0,000$ dapat disimpulkan ada perbedaan yang signifikan antara pengetahuan tentang menghitung gerak janin pada kelompok kasus dibandingkan dengan kelompok control.Hasil uji Fisher's Exact Test $\mathrm{P}=0,000$ dapat disimpulkan ada pengaruh penyuluhan eksperiensial terhadap keaktifan menghitung gerak janin. Merujuk pada kesimpulan penelitian, di rekomendasikan untuk penelitian selanjutnya mengenai efektivitas mengitung gerak janin terhadap deteksi fetal distress.

\section{Ucapan Terimakasih}

Penulis mengucapkan terima kasih pada pemberi dana penelitian ini yaitu Poltekkes Kemenkes Mataram melalui pendanaan penelitian Risbinakes 2018.

\section{Daftar Pustaka}

[1] D'Elia, A., Pighetti, M., Moccia, G.F., Santangelo, M.,. Spontaneous motor activity in normal fetuses. Early Human Development 65, 139-147, 2011

[2] Emilia, Promosi Kesehatan dalam lingkup kesehatan reproduksi. Yogyakarta: Pustaka Cendekia Press, 2010.

[3] Erica O'neill, Md And John Thorp, Md, Antepartum Evaluation Of The Fetus And Fetal Well Being, Clin Obstet Gynecol.; 55(3): 722-730. September, 2012

[4] Kemenkes RI. Pedoman Antenatal Care Terpadu. Jakarta; Kemenkes RI, 2015.

[5] Mangesi L, Hofmeyr GJ. Fetal movement counting for assessment of fetal wellbeing. Cochrane Database Syst Rev.CD004909. 2007.

[6] Petersson K. Diagnostic Evaluation of Fetal Death with Special Reference to Intrauterine Infection. Thesis dari Departement of Clinical Science, Divison of Obstetrics and 
Gynecology, Karolinska Institutet, Huddinge University Hospital, Stockholm, Sweden, 2013.

[7] Prawirohardjo, S. Ilmu Kebidanan Edisi Ketiga Cetakan Kesembilan. Jakarta : Yayasan Bina Pustaka Sarwono Prawirohardjo, 2009.

[8] RCOG, Reduced Fetal Movements, Royal College of Obstetricians Gynaecologists, 57, 2011.

[9] Saastad E, Winje BA, Stray Pedersen B, Frøen JF Fetal Movement Counting Improved Identification of Fetal Growth Restriction and Perinatal Outcomes - a Multi-Centre, Randomized, Controlled Trial. PLoS ONE 6(12): e28482.d 2011.
[10] Saifuddin A.B. Buku Panduan Praktis Pelayanan Kesehatan Maternal dan Neonatal. Jakarta:Bina Pustaka Sarwono Prawiroharjo, 2010.

[11] SDG's, "Panduan SDG's Untuk Pemerintah Daerah dan Pemangku Kepentingan Daerah, INFID, Jakarta, 2015

[12] Winje BA, Saastad E, Gunnes N, et al., Analysis of "count-to-ten" fetal movement charts: a prospective cohort study. BJOG, 118:1229-1238. 2011.

[13] Winkjosastro. Ilmu Kebidanan. Yayasan Bina Pustaka Sarwono Prawirohardjo: Jakarta, 2009. 